\title{
THE BANKRUPTCY LAW AS APPLIED TO STOCKBROKERAGE TRANSACTIONS
}

\author{
Marshatl S. Hagar \\ New York Bar
}

When a stockbroker becomes insolvent and his estate passes into bankruptcy, many intricate questions arise for determination by the bankruptcy court. This is chiefly due to the relationship existing, on the one hand, between himself and his various classes of customers, or between the customers themselves, and on the other hand, between the broker and his bankers or pledgees. In addition to the above, questions of conflicting jurisdiction between state and federal courts are frequent. In numerous failures of large stock brokerage houses ${ }^{1}$ with which Wall Street was visited some ten or twelve years ago the bankruptcy courts early undertook (I) to marshal assets, (2) to determine equities, and (3) to place the seal of authority upon the so-called "Omnibus Proceeding" as an efficient method for determining title and effecting distribution. These were, it is true, but the application of well known equitable doctrines to the complexities of modern business as they appear when the business of the broker is halted and the liquidator of his estate steps in.

The purpose of the writer is to cull from the many decisions what seems to be authoritative and established as the bankruptcy practice in such cases.

It should be carefully noted at the outset of this discussion that all the cases mentioned in the footnotes were decided and certain rules promulgated by the federal courts upon the theory of possession, actual or constructive. The courts of the United States are of limited jurisdiction and the possession of the res draws to it jurisdiction to determine all matters relating thereto. ${ }^{2}$

\section{BROKER'S RELATION TO HIS CUSTOMERS}

Mr. Jones in his work on Pledges summarizes this as follows:

"The broker acts in a threefold relation: first, in purchasing the stock he is an agent; then, in advancing money for the purchase, he becomes a creditor; and, finally, in holding the stock to secure the advances made, he becomes a pledgee of it. It does not matter that the actual possession of the stock was never in the customer. The

\footnotetext{
${ }^{1}$ Jacob Berry \& Co., T. A. McIntyre \& Co., John M. Shaw \& Co., A. O. Brown \& Co., Ennis \& Stoppani, Otto Heintz \& Co.

'In re Rochford (1903, C. C. A. 8th) I24 Fed. I82, 10 Am. B. R. 608; In re Eppstein (1907, C. C. A. 8th) I56 Fed. 42, I9 Am. B. R. 89; In re Kellogg (1903, C. C. A. 2d) 121 Fed. 333, ro Am. B. R. 7 .
} 
form of a delivery of the stock to the customer, and a re-delivery by him to the broker, would have constituted a strict formal pledge. But this delivery and redelivery would leave the parties in precisely the same situation they are in when, waiving this formality, the broker retains the certificates as security for the advance."

\section{Mr. Dos Passos says :}

"Upon the whole, while it must be conceded that there are apparently some incongruous features in the relation, there seems to be neither difficulty nor hardship in holding that a stockbroker is a pledgee; for, although it is true that he may advance all or the greater part of the money embraced in the speculation, if he acts honestly, faithfully, and prudently, the entire risk is upon the client. . . To introduce a different rule would give opportunities for sharp practices and frauds, which the law should not invite."4

The Supreme Court of the United States in the leading case of Richardson $v$. Shaw ${ }^{5}$ adopted the definitions of the above eminent writers as clearly warranted by decisions in the state of New York, where transactions of this character are most numerous, and stated that an examination of the foundations upon which the rule rested made it conclude that in no just sense could the broker be held to be the owner of the shares of stock which he purchases and carries for his customers. The Court took this view, fully recognizing that the Supreme Judicial Court of the state of Massachusetts had reached a different conclusion, namely, that the broker is the owner of the stock purchased, merely carrying the shares upon a conditional contract of sale.

Such had been the rule in New York since $1869,{ }^{6}$ and also in Ohio, ${ }^{7}$ while Massachusetts has clung to the policy that the relation of purchaser of stocks upon margin creates no fiduciary relation between broker and customers, but merely that of debtor and creditor. ${ }^{8}$ The

Jones, Pledges (3d ed. I912) sec. 496.

- Dos Passos, Stockbrokers (2d ed. I905) I96.

${ }^{8}$ (1908) 209 U. S. 365, 28 Sup. Ct. 512; see Robertson v. Allen (I9Ir, C. C. A. 5th) 184 Fed. 372. Cf. Skiff v. Stoddard (I893) 63 Conn. I98, 222, 26 At1. 874, 881 ; Brezuster v. Van Liew (I886) II9 Ill. 554, 8 N. E. 842.

- Markham $v$. Jaudon ( 1869 ) 4I N. Y. 235, the leading case, where it was said at p. 243, per Hunt, C. J.: "I do not find that the intention to have or to suffer a sale, or the reverse, forms an element in the definition of a pledge. Nor do I see how the fluctuating value of the property can be invoked to determine the character of the transaction. It cannot be doubted, upon the authorities cited, that shares of stock in an incorporated company, however unsubstantial may be its character, or however fluctuating their value, may form the subject of a pledge equally with a cargo of wheat, a vessel, or any other specific article. In my judgment, the contract between the parties to this action, was in spirit and in effect, if not technically and in form, a contract of -pledge." See Stenton v. Jerome (1873) 54 N. Y. 480 ; Baker v. Drake (1876) 66 N. Y. 518.

${ }^{7}$ Lamprecht v. State (I9II) 84 Oh. St. 32, 4I, 95 N. E. 656, 657.

"Furber v. Dane (I910) 204 Mass. 412, 90 N. E. 859; In re Swift (1900, D. Mass.) ro5 Fed. 493. 
Richardson Case appears to repudiate this latter doctrine so far as the federal courts are concerned, and in this discussion we shall consider that case as properly defining the relation. Where a broker has been given by a customer the cash or other consideration to buy stocks outright, such customer, upon proper identification, is entitled to the certificates or to the funds, if deposited in a bank and still there at the time of failure. If the broker has diverted the money from the use intended, then he is guilty of conversion and the customer is entitled to his remedies as the law may provide. ${ }^{9}$

\section{RE-HYPOTHECATION OF STOCK}

One of the greatest sources of controversy, has naturally arisen from the broker's re-hypothecation of his customers' securities, and the adjustrient of the respective rights and equities therein. Such action may be rightful or wrongful depending upon the specific contract or the law applicable thereto. The broker's action in such cases may be said to fall into three distinct classes. (I) where he has the absolute right to repledge; (2). where he has a limited right to repledge; (3) where he has no right whatsoever to repledge. These three subheads present many variations and shades of difference. The general rule may be-stated that the broker may re-hypothecate stocks bought for customers on margin when not fully paid for or when his contract with his customer expressly so provides. The customer, not having paid for his purchase, has no right to require the broker to assume in addition to his other duties that of a banker and furnish the unpaid portions of the purchase price; hence the broker almost invariably borrows from his banker or elsewhere in a general or special loan and the certificates for customers' marginal purchases may rightfully go there. The broker's only duty here is to be ready to deliver the stock when the customer takes up and discharges his balance of indebtedness; and he is not obligated to deliver the actual certificates purchased when time for delivery comes, but the equivalent of the purchase in the same kind and class of stock; for a stock certificate has been held to be not the property itself, but the evidence of an undivided proportionate ownership in the property of which each share in the same series has equivalent value without distinction. ${ }^{10}$

- A broker employed to buy stocks for a customer cannot as a general rule sell to his customer the broker's own stock without disclosure of the fact, nor can he buy from the customer, as the relationship is one of trust and confidence and many frauds and abuses would ensue if he were allowed to do so; such a contract is subject to rescission, irrespective of fraud or actual injury. In re Solomon \& Co. (I920, C. C. A. 2d) 268 Fed. I08, 45 Am. B. R. 733.

It was suggested in Porter v. Wormser (r884) 94 N. Y. 43r, 442, that this strict rule might be modified when stock brokers dealt in securities on their own account, and then the relationship might become that of vendor and vendee.

10 "When a broker agrees to carry stock for a customer he may buy stocks to fill several orders in a lump; he may increase his single purchase by stock 
While the broker may hypothecate his customer's marginal stock, the lien of such pledgee is superior to the rights of the customer, and such pledgee ${ }^{11}$ of the stockbroker may sell or otherwise dispose of the stock without notice to the customer and incur no liability to him, though such action may render the broker guilty of conversion if he cannot make good to his customer, upon proper demand. ${ }^{12}$ When, however, the broker becomes insolvent or bankrupt and his pledgee closes out the loan by resort to the pledged securities, it may result, (I) that all the security is exhausted, or (2) all sold, but a cash surplus results, or (3) that some of the security escapes and the loan is satisfied without resort thereto. The securities sold in the latter case may have been selected from the general loan designedly by the pledgee, acting at his own instance or upon request of others, or taken haphazard according to the market or demand, and the residue, whether in stock or cash, left by design or chance, manifestly is not the property of the broker's pledgee, but must be returned to its owners. This may be either to the receiver or trustee of the broker for distribution in the bankruptcy proceeding, or to such owners as may succeed, in outside independent legal proceedings, in identifying and obtaining a court order for their securities.

Instances in general of the above arose very early in bankruptcy proceedings and brought about a proceeding whereby the representative of the estate would apply to the federal court for an order termed for convenience. "Omnibus order," directing all claimants to such securities to file claims thereto or thereon with a master appointed by the order within a limited time fixed by the order and amounting to a short period of limitations, and upon failure to do as provided to be forever foreclosed from making any claim to the specific securities, proceeds thereof, or cash in the hands of such bankruptcy official. Almost uniformly such orders have been upheld as valid.

"We think the court of bankruptcy has as a necessary incident of its duty to administer the bankrupt's estate, the power to summarily dispose

of the same kind that he wants for himself; he may pledge the whole block thus purchased for what sum he likes, or deliver it all in satisfaction of later orders, and he may satisfy the earlier customers with any stock that he has on hand or that he buy's when the time for delivery comes. Yet as he is bound to keep stock enough to satisfy his contract, as the New York firm in this case was bound to substitute other security if it withdrew any, the customer is held to have such an interest that a delivery to him by an insolvent broker is not a preference. ... So a depositor in a grain elevator may have a property in grain in a certain elevator although the keeper is at liberty to mix his own or other grain with the deposit and empty and refill the receptacle twenty times before making good his receipt to the depositor concerned." Sexton v. Kessler \& Co. (1912) 225 U. S. $90,97,32$ Sup. Ct. 657, 659, 28 Am. B. R. 85, 87.

${ }^{12}$ Purchase of pledged stock at sale by pledgee in regular way conveys a good title to the particular securities as against bankrupt's customers. In re Stringer (Igr6, E. D. N. Y.) 230 Fed. I77, 37 Am. B. R. 44.

${ }^{22}$ Rothschild v. Allen (1904) 90 App. Div. 233, 86 N. Y. Supp. 42, affirmed in (1905) 180 N. Y. 561,73 N. E. II32. 
of claims to assets in its possession. Of course notice must be given to the claimants and a reasonable time afforded them within which to prove their claims." ${ }^{\prime 3}$

The same court in Matter of Lathrop, Haskins \& Co. ${ }^{14}$ again approved such an order, observing,

"But the court sought by its order to require persons claiming stocks or bonds then in the possession of the receiver, or which might subsequently come into his possession, or into the possession of the trustee, to give notice of their claims within a time specified, or be barred of the right to recover them from the receiver or trustee. We are at a loss to understand why the authority of the court to make such an order should be denied. It is said that such an order is in effect a short statute of limitations, and that as such beyond the power of the court to establish. In making the order the court was in the exercise of its equity jurisdiction. The equity courts, in jurisdictions where the distinction between law and equity is maintained, while not bound by statutes of limitation not in totidem verbis applicable to equitable demands, have nevertheless from the earliest times asserted the right to adopt and apply statutes of limitation to cases over which their jurisdiction was concurrent with that of the courts of law. And in cases over which the courts of equity have exercised an exclusive jurisdiction they have acted upon the maxim vigilantibus non dormientibus aequitas subvenit, and recognized laches as a defense peculiar to the chancery courts, and refused to grant relief to one who has unduly delayed the prosecution of his claim. And it has also been the practice of equity courts in appointing receivers to limit the time within which claimants could assert a claim against the receivers so appointed. In the exercise of the right thus to limit rights of action the equity courts have not derived their power from any statute but have exercised an inherent power. It is too late in the history of these courts to challenge their right in this respect."

"The order expressly provided that it was 'not to be construed to bar any creditor from his right to file a proof of claim as general 'creditor against this estate within one year after the order adjudicating 'the above named bankrupts.' In other words, the order did not fix a time for general creditors to file claims against the estate. That the court could not have done, as the Bankruptcy Act, in providing in section 57 , subd. ' $n$,' that 'claims shall not be proved against a bankrupt "estate subsequent to one year after the adjudication,' plainly implies that creditors shall be entitled to file claims at any time within the year."

In the latter case the order was held good as to securities coming into the hands of the receiver after the date of the order itself, Judge Ward dissenting on the ground that it was beyond the power of the court to bar claimants before it had the res in its hands. The majority opinion, however, ruled that in so holding the court was within the well recognized equity jurisdiction of the district courts. ${ }^{15}$

${ }^{13}$ In re T. A. McIntyre \& Co., Petition of Pierce (I9Io, C. C. A. 2d) 176 Fed. 552, 553, 24 Am. B. R. 4, 21.

is (I915, C. C. A. 2d) 223 Fed. 912, 9I7, 34 Am. B. R. 739, 746.

15 "Omnibus order," determining the rights of various claimants to property in the hands of a receiver, is reviewable by petition to revise, and not by appeal. In re Pierson (1916, C. C. A. 2d) 233 Fed. 519, 37 Am. B. R. 10; In re Rose Shoe 
When the courts were called on to deal with the second and third classes enumerated above, i. e., when the broker had only a limited or conditional right to repledge or no right at all to repledge his customers' securities, certain fundamental rules were early recognized and applied. When the broker's act amounted to larceny, the rights of such customers were deemed of the highest and for convenience are usually designated in the cases as belonging in Class A. Owners of stock converted by a bankrupt firm of stockbrokers were held entitled to similar stock in the bankrupt's possession at time of adjudication as tenants in common and were not confined to certificates, actually in the broker's hands, and the Circuit Court of Appeals for the Second Circuit in T. A. McIntyre and $\mathrm{Co}^{16}$ said:

"The bankrupts disposed of securities which belonged to several of their customers, and deposited the proceeds in one of their general bank accounts. Their drawings exhausted their own funds therein, and also such proceeds. Subsequently deposits were made, and at the time of failure there was over $\$ I I, 924.83$ balance in bankrupt's favor. The proposition presented is this: When a trustee has drawn out moneys which belonged to several different persons, and thereafter makes a deposit, shall such deposit be considered as a general restoration, in which all the defrauded cestuis que trustent will share ratably, or is it to be treated as making good so far as it will go the separate amounts converted from each in the order in which they were abstracted? We concur with the special master and the District Judge in the conclusion that it is to be assumed the defaulter intended whatever repayment he made to apply on the entire default, and did not. intend to prefer the person whose money he first abstracted, by first making him whole at the expense of all the others.

"Bankrupts bought 200 shares of a certain stock for a customer. They did not keep this stock, but used it as they would their own in the general transaction of their business. They did the same with other customers who had bought like stock. When they failed there were 95 shares of this kind of stock among the Bank of Commerce collateral, 1o shares were pledged on another loan, and there were 2 shares in their vault. They owed their customers $I, 65 I$ shares of this variety of stock. We cannot find from the record any satisfactory identification of the 95 shares (or any of them) as being those bought for this particular customer, rather than those bought for some one else."

\section{RULE IN PIPPEY'S CASE}

In the same case of $T$. A. McIntyre \& $\mathrm{Co}^{17}$ was enunciated the so-called "Rule in Pippey's Case," oft quoted and discussed. The facts here were that on March I4, 1908, Pippey, owning a certificate

Mfg. Co. (Igog, C. C. A. 2d) I68 Fed. 39, 21 Am. B. R. 725. Cf. as to reclamations brought by the claimants themselves, In re Solonon \& Co., supra note 9.

Inherent power of court of equity upheld in Penn. Steel Co.v. N. Y. City Ry. (1912, C. C. A. 2d) Ig8 Fed. 721.

When securities are not in its possession, see First National Bank v. Chicago Title \& Trust Co. (1905) 198 U. S. 280 , 15 Sup .Ct. 693.

13 Petition of Grace (1910, C. C. A. 2d) I8r Fed. 960, 96r, 25 Am. B. R. 93, 95.

${ }^{27}$ Petition of Pippey (1910, C. C. A. 2d) 18I Fed. 955, 958, 24 Am. B. R. 626, 629. 
for, 18 shares of Pullman stock standing in his name, endorsed it in blank and delivered it to the firm of McIntyre \& Company as security for future transactions, but with no authority to repledge. Certain transactions were had, but on April 9 all pending transactions were closed 'out with a credit balance due Pippey. On April 23rd McIntyre $\&$ Co. pledged Pippey's stock as substituted collateral upon its general loan with a trust company and on the following day an involuntary petition was filed against the firm and a receiver of its property appointed. On the next day Pippey applied to the receiver for his stock and was informed that it was in possession of the trust company. He notified the trust company not to sell his certificate and demanded it. Upon refusal he brought a replevin action in the state court against the trust company for his stock, but was restrained from prosecuting it by order of the District Court. His stock was not used in satisfaction of the general loan and was returned by the trust company to the receiver of the bankrupt firm. It is apparent that McIntyre \& Co. were guilty of larceny in using this stock and that Pippey, in endorsing the certificate in blank, only estopped himself as against the trust company if it had used the certificate in satisfaction of the bankrupt's loan: The loan having been liquidated without resort to this certificate, Pippey's title thereto became absolute. The court then proceeded to lay down the rule as follows:

"Instead of directing the trustees to return his stock to Pippey, the court has ordered it to be sold and the proceeds put into a fund with the proceeds of the 300 shares International Power Company and the 200 shares American Can Company and the $\$ 832.16$ surplus realized by the trust company from the securities which it sold to repay the $\$ 200,000$ loan. In this fund Pippey is to share with others whose stock was improperly pledged by the brokers with the trust company and sold by it. The amount coming to him would be less than his stock. This is practically applying the principle of general average to the situation. The pledge is treated as a common adventure, the securities sold as a sacrifice for the common benefit, to which all interests are required to contribute. We do not think Pippey can be thus required to contribute. If he had been left undisturbed to prosecute the replevin suit, he would have recovered the specific piece of property, which he owned, had identified, and was entitled to. By not appealing from the original order, and by prosecuting his claim of his stock in the bankruptcy court, he did not abandon any of his legal rights, nor obligate himself to contribute to the reimbursement of any one whose stock had been sold."18

That the courts have chafed under this ruling as inequitable and as working inequalities between claimants with equal standing, is apparent

\footnotetext{
${ }^{18}$ Gould v. Farmers' Loan \& Trust Co. (188a, N. Y. App. Div.) 23 Hun, 322, and Whitlock v. Seaboard National 'Bank (1899, Sup. Ct.) 29 Misc. 84,60 N. Y. Supp. 6ri, have been held not to control by the New York Supreme Court, Appellate Division, when property stolen from its real owner is found unsold in the possession of the assignee of the thief. Tompkins $v$. Mortor Trust $C o$. (1904) 91 App. Div. 274, 285, 86 N. Y. Supp. 520, 528.
} 
from the efforts made to distinguish and break away from the general language of the opinion. For example, Judge Mayer of the District Court for the Northern District of New York, in his elaborate and well considered opinion in Matter of Wilson $\&$ Co. ${ }^{19}$ even took occasion to examine the original records in the McIntyre Case (Petition of Pippey), and said that from such examination it was apparent that there were other claimants similarly situated with Pippey and entitled to stock on an equally meritorious basis, who, however, did not appeal from the order below, and apparently acquiesced therein. In the language of the court:

"If, however, Mrs. M. or Mrs. S. and the others similarly situated had also appealed, is it to be supposed that the court would have held that Pippey could reclaim all of his stock, and others similarly situated must leave the court emptyhanded, because of the fortuitous circumstances that the pledgee after bankruptcy had sold the stock of Mrs. M. and Mrs. S., for instance, and has not sold the stock of Pippey?"

He concludes that the court in that case felt compelled to award relief only to those who sought it by appeal or petition to review; that while rejecting the admiralty principle of general average, the court did not disturb the proposition that it is the character of the equity which determines the classification of a claim, and ordinarily the value of securities should be taken as of the date of filing of petition.

"Equity will treat alike those similarly situated," it seems ought to be the prevailing maxim in these cases, and where contribution is necessary to cover the expenses of the proceeding, no one claimant should be permitted to take away his stock without such a burden, when others in the same class are called upon to contribute because their stock had chanced to be sold by the broker's pledgee. ${ }^{20}$

\section{IDENTIFICATION OF STOCK AND SUBROGATION}

In Gorman v. Littlefield, ${ }^{21}$ a case growing out of the bankruptcy of A. O. Brown \& Company, Wall Street brokers, the Supreme Court held and established the rule that owners of converted stock are not necessarily confined to the specific identification of their shares of stock.

"It is enough that the broker has shares of the same kind which are legally subject to the demand of the customer. And in this respect the trustee in bankruptcy is in the same position as the broker. Richardson v. Shaw, supra.

"It is said, however, that the shares in this particular case are not so

In re Wilson \& Co. (rg17, N. D. N. Y.) 252 Fed. 631, 42 Am. B. R. 350, 359.

Judge Manton in his opinion in In re Amy (I920, C. C. A. 2d) 263 Fed. 8, $45 \mathrm{Am}$. B. R. 15, seems to hold to the contrary on jurisdictional grounds, where the trustee lays no title to the res.

${ }^{21}$ (1913) 229 U. S. I9, 24, 33 Sup. Ct. 690,691; 30 Am. B. R. 266, 269. 
identified as to come within the rule. But it does appear that at the time of bankruptcy certificates were found in the bankrupt's possession in an amount greater than those which should have been on hand for this customer, and the significant fact is shown that no other customer claimed any right in those shares of stock. It was, as we have seen, the duty of the broker, if he sold the shares specifically purchased for the appellant, to buy others of like kind, and to keep on hand subject to the order of the customer certificates sufficient for the legitimate demands upon him. If he did this, the identification of particular certificates is unimportant.",22

This rule is not confined to stock certificates actually in the broker's box on day of failure. ${ }^{23}$

Where brokers wrongfully pledged securities belonging to their customers as collateral for a loan in their bank, and upon their bankruptcy the bank under the terms of a collateral note applied the deposit of the brokers upon the note and sold the securities, leaving a balance, the owners of the securities are held to be subrogated to the rights of the bank in the deposit and are entitled to the possession thereof as against the trustee in bankruptcy of the brokers. ${ }^{24}$

So where a customer furnishes the broker with funds upon specific orders to buy stocks and apply the payment to the purchase price, and the broker does not buy, but has the money, ear-marked, in his possession on date of bankruptcy, the customer and not the trustee is entitled to this money. ${ }^{25}$

It is interesting to follow the Gorman v. Littlefield doctrine as applied by the courts in the Hollins Case. ${ }^{26}$ In this case a petition in -bankruptcy was filed November 15, I9I3. Prior to that date the brokers had made the following purchases for customers of Amalgamated Copper; October 25, 1912, for B, 30 shares; October 30, I9I2, for D, 30 shares; February 5, 1913, for W, 50 shares; October 28, 1913, for L, I00 shares. On the day the petition was filed, the bankrupts had in their box roo shares of the stock of this company; of the remaining 180 shares, 30 had been pledged with the bank, 50 had been pledged with the trust company, and roo had been used for delivery covering a "short" order for another customer; that is, had been loaned to that customer. After the filing of the bankruptcy petition, $D$ and $W$ offered to pay their indebtedness on account of the bankrupt; $L$ and $B$ did not do so; D petitioned the court for I00-280ths of the Ioo shares of copper in the possession of the bankruptcy receivers, and $W$ asked for 50280 ths of same. Judge Hough, before whom these applications came in the District Court, granted the motion, holding further that $\mathrm{L}$ and $\mathrm{B}$

Where claimants have failed to prove their claim to a pro rata share, such failure cannot enlarge the pro rata of those who have traced. In re Pierson, supra note 15; In re Wilson \& Ca. supra note 19.

${ }^{2}$ In re Pierson, supra note 15.

"In re Leavitt \& Grant (1914, C. C. A. 2d) 215 Fed. 901, 33 Am. B. R. 63; In re Gay \& Sturgis (1918, D. Mass.) 25I Fed. 420, 4I Am. B. R. 560.

${ }^{25}$ In re Wettengel (1916, C. C. A. 3d) 238 Fed. 798, 38 Am. B. R. 444.

In re Hollins (1914, S. D. N. Y.) 212 Fed. 317, reversed in (I9I4, C. C. A. 2d) 219 Fed. 544, 34 Am. B. R. 34. See note 29 infra. 
would have been respectively entitled to roo-280ths, and 30-280ths, had it not been for the fact that they could not recover without paying their indebtedness to the receiver, which they had not offered to do. In other words, he felt constrained by the decision in Gorman v. Littlefield to apply the "grain in a bin" doctrine, and because it could not be determined for which particular customer or customers the too shares of copper stock were held, he reached the conclusion that all claimants to copper stock were in the same class and were entitled to share ratably in the shares of that stock on hand. The Circuit Court of Appeals, in reviewing these orders from which the receiver and the bankrupt appealed, reversed the District Court on the ground that the identification was insufficient and that equity would seem to require that the funds for general creditors should not be depleted on any theory that had not the sanction of controlling authority. It stated that in arriving at this conclusion it was following its own decision in a prior case, In re McIntyre, Petition of Grace, ${ }^{27}$ in which it held there was insufficient identification. The theory here relied on was submitted with petition for certiorari in that case but certiorari was refused. ${ }^{28}$

When the Hollins Case reached the Supreme Court, ${ }^{29}$ that court held that a logical application of the principles of Gorman $v$. Littlefield $^{30}$ required a disagreement with the Circuit Court of Appeals and an approval of the District Court, although the facts were somewhat different;

"And merely because the one [certificate] actually in the box represented insufficient shares fully to satisfy all is not enough to prevent application of that rule so far as the circumstances will permit."

Mr. Justice Pitney dissented (Mr. Justice Hughes concurring), saying that in the present case it did not appear at the time of the filing of the bankruptcy petition that certificates of stock were in the broker's possession equal to those which should have been on hand; that it affirmatively appeared that the brokers, having sold the shares specifically purchased for these customers, had not bought any of like kind or had kept on hand certificates sufficient for claims of customers for them. Not only was no stock kept on hand to answer the claims, but it appeared that the roo shares which were on hand were not acquired with intent to make restitution; that from the record as to this it appeared that the Ioo shares received from the Stock Exchange Clearing House in the usual course of business as representing the balance of Amalgamated Copper due to said firm on balance on said date and not connected in any way with the account of the appellants or either of them, and then Mr. Justice Pitney makes the following observations as to the theory of restitution:

\footnotetext{
"Supra note 16.

${ }^{2}$ Grace v. Burlingham (19ro) 218 U. S. 672, 31 Sup. Ct. 221.

${ }^{20}$ Duel v. Hollins (1916) $24 \mathrm{I}$ U. S. 523, 529, 530, 36 Sup. Ct. 615, 617, 37 Am. B. R. I, 5, 6 .

${ }^{*}$ Supra note 21.
} 
"It is one thing to infer an intent to make restitution to a customer when the acts have been done that are necessary to effect restitution; it is an entirely different matter to infer an intent to make restitution when no restitution has in fact been made. The presumption of an intent to restore fractional interests in this case must rest on the merest fiction; and such a fiction ought not to be indulged in cases of this character, where it will inevitably result in creating a series of arbitrary preferences, contrary to the equity of the Bankruptcy Act."

\section{STOCKHOLDERS REMEDIES ${ }^{31}$}

In In re Enniis ${ }^{32}$ an action was brought against, the brokers for conversion by one Roche, alleging conversion of his stock which had been held by them as pledgees for the repayment of part of the purchase price. The complaint alleged that "The defendants converted said "stocks to their own use and benefit in fraud of the rights of the "plaintiff." The defendants had been arrested in the state court and had given bail procured from a surety company to answer the judgment. The bankrupts had indemnified the surety company, all of which had taken place more than four months prior to the filing of the petition. A motion was made to vacate the stay preventing Roche from proceeding to judgment. Learned Hand, J., ruled that the plaintiff, having elected to sue in conversion and not to rescind for fraud or imposition, had affirmed the contract; that the debt was a dischargeable one under the decisions as they then stood, that the stay should be vacated and the petitioner be allowed to proceed to judgment, and take such action as he might elect against the surety. ${ }^{33}$

The United States Supreme Court in the case of McIntyre v. Kavanaugh seems to have settled the law that stockbrokers guilty of a deliberate conversion come within the provisions of section I7a (2) of the Act, "wilful and malicious injury to the property of another," and the debt thus created is not dischargeable. Since the passage of the "Stillwell Act" in New York in I9I3, making unlawful rehypothecation a felony on the part of the broker, the courts of that State have distinguished the doctrine of Wood $v$. Fis $k^{38 a}$ and consider such acts of a stockbroker as amount to conversion under that law within the category of wilful and malicious injury to the property of another and therefore excepted from the operation of a discharge.

The case of In re Amy, ${ }^{34}$ recently decided by the Circuit Court

\footnotetext{
${ }^{31}$ See In re Solomon-\& Co., supra note 9, holding that reclamation of third party from a receiver is a controversy arising in bankruptcy proceedings and an appeal is the proper remedy under sec. 242 of the Act.

(I909, S. D. N. Y.) I7I Fed. 755, 22 Am. B. R. 679.

${ }^{23}$ See the Bankruptcy Act, secs. I7a (2), 63a (I); see also Kavanaugh $v$. McIntyre (1908) 128 App. Div. 722, 112 N. Y. Supp. 987, 21 Am. B. R. 327, aff. in (1914) 210 N. Y. 175, 104 N. E. I35, and in error to Supreme Court sub nom. McIntyre v. Kavanaugh (1916) 242 U. S. 138, 37 Sup. Ct. 38, 38 Am. B. R. 165.

$2 z_{2}$ (1915) 215 N. Y. 233 , 109 N. E. I77. See Heaphy v. Kerr (I920) 190 App. Div. 810, 180 N. Y. Supp. 542, 45 Am. B. R. 53. See also In re Northrup (1920, N. D. N. Y.) 265 Fed. 420,45 Am. B. R. 724, refusing a stay in conversion action.

supra note 20.
} 
of Appeals for the Second Circuit, is illuminating on the jurisdictional rights of a creditor whose securities had been misappropriated. An action to replevy $\$ 2000$ worth of railroad bonds was brought in the New York supreme court against this brokerage firm and its assignee for the benefit of creditors. These bonds had been in the possession of this firm long previous to the assignment and at some time prior thereto had been hypothecated in a general loan under such circumstances as to constitute larceny both under the "Stillwell Act" 35 and the decision in the McIntyre Case. ${ }^{36}$ These particular bonds had chanced to survive the sale of its collateral by the pledgee. Bankruptcy of the Amy firm having intervened, the assignee for creditors became the trustee and as such applied in the District Court to restrain further prosecution of the above action. The plaintiffs' attorneys appeared specially on the motion to object to the jurisdiction of the court, and thus was the question of the District Court's power to grant these stays against replevin actions wherein the trustee claims no substantial interest in the property, squarely raised.

The point was adverted to back in I9Io in the McIntyre Case ${ }^{37}$ by Judge Lacombe, but not being before the court at that time, was not decided. His language then was :

"It is now contended that the District Court had no jurisdiction to make such an order, so far as Pippey and his stock were concerned. Whether or not that court had jurisdiction to authorize its officers to take possession of the property of a third person, not then held by the bankrupt, but in the hands of another person, who asserted no title to it, a controversy as to its possession between the owner and the custodian being then actually pending in the state court, so that the property had been brought within the jurisdiction of such state court, is a question we need not now decide. No appeal from or petition to revise this order was taken within the time allowed; but Pippey appeared before the special master and litigated his case."

Until the instant case there seems to have been no authoritative ruling on this jurisdictional question.

As in the McIntyre Case the trustee of $\mathrm{H}$. Amy \& Co. asserted before the District Court no substantial title to the securities, but moved for his stay in order to have all rights therein disposed of in the usual "Omnibus proceeding."

The motion for a stay was denied in the court below and review was sought. The Circuit Court of Appeals upheld its own right to determine the question of jurisdiction, and held that such questions do not pass directly from the District Court to the Supreme Court.

Manton, J. said, ${ }^{38}$

"Since the bankrupt had no ownership interest in any of the bonds, which were hypothecated, and which were sold contrary to the rights of their true owners, no possible advantages could result to the creditors of the estate of the bankrupts, and the ratable distribution of the

\footnotetext{
${ }^{35}$ Consol. Laws N. Y., 1909, ch. 88, sec. 956; Laws 1913, ch. 500, sec. 956.

* Petition of Pippey, supra note 17. ${ }_{37}^{\text {Ibid. }}$

263 Fed. 18, 10, 45 Am. B. R. 15, 18.
} 
proceeds of the stolen property could not serve to increase the amount of the assets, or to reduce the total amount of the provable claims against the estate. The contest as to the interest in the stolen property; since it was no part of the estate of the bankrupts, is of no interest to the trustee. The Bankruptcy Act makes provision for the search or discovery of concealed assets by providing for the examination of the bankrupts and others; and, even assuming that an examination revealed this property in possession of the bankrupts at the time the petition was filed, the trustee could not retain possession of the stolen property, and would be obliged to return it, if possession were taken, to the lawful owner. It is inconceivable to believe that any greater right exists where the property is unlaw fully held after wrongful conversion by a party other than the bankrupt.

"But it is contended by the trustee that demands have been made upon him for these bonds by claimants who have lost their respective securities. By depositing the bonds or proceeds with the clerk of the court, and asking for an interpleader, the trustee would protect the estate against such demands. . .

"We conclude that the court below properly denied the application for a stay, and the order is therefore affirmed."

To conclude, then, a stockholder, having identified his securities or their proceeds, ${ }^{39}$ and not having sued the broker for his alleged wrongdoing prior to the filing of the petition, may then reclaim in the bankruptcy court his securities actually or constructively in the possession of the bankruptcy officer; so also he may abandon, if he desires, his state court action theretofore brought and reclaim in the federal court; or lastly, he may prove his claim to specific stocks or bonds in a general "Omnibus proceeding;" or he may file his claim as a general creditor to receive a ratable distribution, thereby waiving any claim to specific securities. As was cogently remarked by Judge Mayer,

"The logical procedure it seems to me is that the first requirement laid upon a claimant is to trace his stock or its identifiable proceeds. If he fails in that regard, no matter how grievous the wrong, he becomes a general creditor. ${ }^{40}$

${ }^{30}$ Skiff v. Stoddard (1893) 63 Conn. 198, 225, 26 Atl. 874, 883.

${ }^{2}$ In re Wilson \& Co. (19I7, N. D. N. Y.) 252 Fed: 631, 42 Am. B. R. 350. As to the doctrine of unjust enrichment of an estate by the addition of wrongfully converted securities the same judge has this to say: "In the $R$. claim at bar, and in similar claims, the difficulty is that the proceeds cannot be traced. It may or may not be that these proceeds are somewhere in the cash and securities heretofore or now held by the Guaranty Trust Company; but who can say? There is no doubt that the $W$. estate was unjustly enriched, because the conversion of these 200 shares of Southern Pacific resulted in reducing the indebtedness of W. to $\mathrm{H}$. pro tanto; but that is not enough. If the doctrine of unjust enrichment is to be applied to this case, then it follows that every conversion, whether the proceeds thereof be traced or not, will give a claimant of this character remedies heretofore never accorded. All that will be necessary will be to show that securities were converted without the paramount further requirement of demonstrating beyond question that the proceeds of the conversion are in a fund where they can be unequivocably identified. In re A. D. Matthews' Sons, Inc. (I916, C. C. A. 2d) 238 Fed. 785,38 Am. B. R. 438 ." 